\title{
The age of criminal responsibility and juvenile justice in mainland China: a case study
}

ANQI SHEN*

Teesside University

\begin{abstract}
This article is about the rules on age and crime in relation to juveniles in mainland China. It starts with an outline of the Chinese law on age and crime in relation to children and young people. This is followed by a brief analysis of the international legal framework - norms, standards, rules and guidelines pertaining to global child protection and juvenile justice policies. It then moves on to examine juvenile justice policy and practice in China, the reality of juvenile offending in the country and, accordingly, the calls for reform of the age of criminal responsibility. Finally, it concludes that China's problem is not about a low age of criminal responsibility or resistance to the international law, but more to do with a deeper understanding of it and implementation. From a comparative perspective, it utilises China as a case study to claim that attention in juvenile justice in any given jurisdiction should be shifted away from (re)setting the minimum crime age to the development of child-centred juvenile justice that should be research-informed, under the human rights framework and that moves away from the legal institutions and the disproportionate punitive interventions.
\end{abstract}

\section{Introduction}

$\mathrm{T}$

The minimum age when children may be held criminally liable for serious wrong-doing diverges considerably across jurisdictions: the lowest crime age in the world is 7; the minimum age of criminal responsibility is 10 in England, 15 in the Nordic countries, and 18 in Belgium and Luxembourg. Like the majority of European countries, it is 14 in the mainland of the People's Republic of China (PRC).

The rules on age and crime in mainland China are two-tiered under s 17 of the Chinese Criminal Law 1997 (CCL 1997):

A person of 16 years of age who commits crime shall be criminally responsible; a person of 14 years of age but below 16 shall be criminally responsible for murder, assault causing death(s) or grievous bodily harm, rape, robbery, drug trafficking/drug dealing, arson, bombing, and/or poisoning.

Reader in Law, School of Social Sciences, Business and Law. Email: anqi.shen@tees.ac.uk. I would like to thank Jiangsu Collaborative Innovation Centre for Development of Regional Rule of Law (China) for funding. An earlier version of this paper was presented at the International Symposium on Regional Governance and Development of the Rule of Law held in Nanjing, China in April 2016. 
Therefore, in Chinese law, 14 is the age of relative criminal responsibility ${ }^{1}$ and relevant to juveniles at ages 14 and 15 who commit eight grave offences; but 16 is the age of full criminal responsibility. Chinese law provides that a young person of age 14 but below 18 shall receive a lighter or mitigated sentence for criminal acting. Those under 18 at the time of offending shall not be liable to the death penalty. ${ }^{2}$ In this sense, 'juvenile offenders' refers to juveniles who have reached the age of criminal responsibility, but are below 18 , commit crime, and are treated differently from adult offenders in the Chinese criminal justice system. Juveniles of 14 and 15 years of age who commit less serious offences and thus are immune from the penal law may appear before a judge at the trial division for juveniles. Their parents or guardians may be ordered to exercise supervision; where necessary the juveniles may be subject to 'shelter for rehabilitation' by the state. ${ }^{3}$ It appears that Chinese law regulates the age of criminal responsibility along with how children and young people should be dealt with once they come to be in contact with the criminal law.

The rules on age and crime are fairly consistent in mainland China. Prior to 1997, similar rules were adopted in the PRC's first criminal code. ${ }^{4}$ It stated:

A person of 14 years of age but below 16 who commits crime shall be criminally responsible for homicide, causing grievous bodily harm, robbery, arson, habitual theft, and other crimes of seriously undermining the social order. (emphasis added)

Compared with the rules in the CCL 1979, the scope of offences relevant to the age of relative criminal responsibility is narrowed significantly in the current law which covers eight specified offences that reflect the seriousness of criminal acts, the crime reality in relation to juveniles and also the official emphasis of care for children. Apart from this, the general principles remain.

The Supreme People's Court Criminal Law Revision Office explained the rationale for the rules in the 1979 law:

The vast majority of juvenile offenders are in the age range of 16 and 25; children below age 14 are rarely involved in serious criminality. While some children today do mature earlier than before, it is not the case among over 80 per cent of the rural child population. Lowering the minimum crime age would be in contrary to our juvenile justice policy - education first; punishment second. Also, the majority of jurisdictions have fixed their age of criminal responsibility at $14 .^{5}$

There is no similar information for the current law. Given that there have been no radical policy shifts in this area, it is reasonable to believe that the same factors were considered to rationalise the current rules. Several interpretations can be offered. First, a combination of factors seems to have been taken into account when the age of criminal responsibility was settled in China. These include the relationship between children's involvement in crime and their age, the facts of physical and cognitive maturity, the juvenile justice policy in China and the policy and practice in other jurisdictions. China appears to have taken a rather balanced approach to determining the age of criminal responsibility, several years prior to the 'Beijing Rules' ${ }^{\text {' }}$ that were adopted by the UN General Assembly in 1985 as

1 Gerrard Maher, 'Age and Criminal Responsibility' (2005) 2 Ohio State Journal of Criminal Law 493.

2 CCL 1997, s 49.

3 Ibid s 17.

4 CCL 1979, s 14 (2).

5 Mingxuan Gao and Bingzhi Zhao (eds), Collection of New China Criminal Legislation Source Materials (Xia) (China People's Security University 1997) 2233-34.

6 UN Standard Minimum Rules for the Administration of Juvenile Justice 1985, known as the Beijing Rules. 
the first international guidelines concerning the development of separate and specialist juvenile justice systems for the purpose of protection for children.

Second, as in other countries, the age of criminal responsibility is recognised in China where the law deems that at a certain age children should know the difference between right and wrong and thus it is necessary to hold these children accountable for criminal actions. However, since there was no conclusive neuro-psychological evidence for child development, the minimum crime age was arbitrarily fixed in Chinese law, as it has been in many other jurisdictions, resulting in continuous debate as to whether the minimum age ought to be increased or decreased.

Third, the age of criminal responsibility in China is largely in line with international law that is contained in a range of international conventions, treaties, standards, rules and guidelines concerning children's interests and rights. ${ }^{7}$ Chinese law in this respect appears to be a step ahead of that of several Western, developed systems, some neighbouring countries and many other nation states across the rest of the world. Consequently, unlike Britain, ${ }^{8}$ China is under no pressure in terms of compliance with international law for fixing the minimum crime age for juveniles.

Comparatively speaking, China does not have a low age of criminal responsibility. However, once the minimum crime age is reached, the juvenile can be arrested, prosecuted and punished. It is true that substantive criminal law in China differentiates juveniles from adults when defining crime and punishment and procedural law and laws concerning child protection recognise a need to use special measures for juveniles, ${ }^{9}$ but it is not difficult to find gaps in law, policy and practice in terms of how offending children should be treated as far as international law is concerned. This article sets out to discuss the rules on age and crime in China and also examines how juvenile law-breakers essentially children who are typically from disadvantaged backgrounds in society ${ }^{10}-$ are dealt with in the Chinese system.

It starts with an outline of the Chinese law on age and crime in relation to children and young people. This is followed by a brief analysis of the international legal framework - norms, standards, rules and guidelines - pertaining to global child protection and juvenile justice policies. It then examines juvenile justice policy and practice in China, the reality of juvenile offending in the country and recommendations for reform to the age of criminal responsibility. It concludes that China's problem is not the low age of criminal responsibility or resistance to international law, but the understanding and implementation of the law. From a comparative perspective, China is utilised as a case study to claim that attention in juvenile justice in any given jurisdiction should be shifted away from (re)setting the minimum crime age to the acceptance and development of child-centred juvenile justice that should be research-informed and aligned with the international human rights framework. This would engage a departure from current legal institutions and disproportionate punitive interventions.

7 For example, the Beijing Rules; the UNCRC; the UN Guidelines for the Prevention of Juvenile Delinquency, adopted by the General Assembly Resolution 45/112 of 14 December 1990 (the Riyadh Guidelines); the UN Rules for the Protection of Juveniles Deprived of their Liberty, adopted by the General Assembly Resolution 45/113 of 14 December 1990 (the JDLs); the General Comment No 10: Children's Rights in Juvenile Justice CRC/C/GC/10, Geneva (CRC 2007).

8 John Muncie, 'The United Nations, Children's Rights and Juvenile Justice' in Wayne Taylor, Rod Earle and Richard Hester (eds), Youth Justice Handbook: Theory, Policy and Practice (Willan 2009) 200-11.

9 Anqi Shen, 'The Role of the Study-Work School: A Chinese Case Study on Early Intervention and ChildCentred Juvenile Justice' (2016) 16(2) Youth Justice 95.

10 Muncie (n 8). 


\section{International legal framework: safeguarding juveniles in conflict with the law}

In the following pages, the international legal framework is outlined to illustrate the global benchmarks for examining policy and practice in China as regards the protection of children who offend.

Scholarly literature on the minimum age of criminal responsibility often makes reference to the capacity responsibility of children. ${ }^{11}$ It is assumed that 'an age' should, and can, be found to 'appropriately' hold child law-breakers accountable. Over the years, efforts have been made to advance the legal norm of the age of criminal responsibility by seeking support from neuro-psychological findings in respect of the moral development of children. ${ }^{12}$ So far, no consensus has been reached in this area of psychology.

International law, however, takes a rather different approach and provides the rules and guidelines in rights discourses, which seek to safeguard children's rights and interests in juvenile justice. There are a range of human rights treaties, for example, the UN Convention on the Rights of the Child (UNCRC), as well as non-binding international instruments that seek to provide a 'unifying legal framework' for juvenile justice policy on a global scale. ${ }^{13}$ Together, they help identify international norms and standards that guide how contracting states determine approaches in consonance with international agreements. These rules and guidelines direct the level at which the minimum age of criminal responsibility should be set and safeguard the appropriate treatment for juveniles in conflict with the law. The term 'international law' is used broadly in this article to include both the binding agreements and the official guidelines associated with them.

\section{INTERNATIONAL LAW ON THE AGE OF CRIMINAL RESPONSIBILITY}

The starting point lies in the Beijing Rules - a non-binding official document providing recommendations on the protection of juveniles who offend:

In the legal systems recognising the concept of the age of criminal responsibility for juveniles, the beginning of that age shall not be fixed at too low an age level, bearing in mind the facts of emotional, mental and intellectual maturity. ${ }^{14}$

International law provides general guidance and it appears to accept national variations, recognising that childhood maturity may differ across jurisdictions due to political, social, cultural and historical conditions.

The UNCRC, which recognises children's rights worldwide, offers detailed rules on the age of criminal responsibility for juveniles. Article 40.3(a) provides that states parties shall seek to promote 'the establishment of a minimum age below which children shall be presumed not to have the capacity to infringe the penal law'. Below the minimum crime age children have absolute immunity from the penal system. For Maher, legal systems in the world tend to use the age of criminal responsibility in two discrete ways: one concerns the capacity of a child to commit a crime; the other relates to exemption of a child from the 'full' or adult system of prosecution and punishment. ${ }^{15}$ International law seems to

11 Maher (n 1) 512.

12 Nuno Ferreira, 'Putting the Age of Criminal and Tort Liability into Context: A Dialogue between Law and Psychology’ (2008) 16 International Journal of Children’s Rights 29.

13 Barry Goldson and Gordon Hughes, 'Sociological Criminology and Youth Justice: Comparative Policy Analysis and Academic Intervention' (2010) 10(2) Criminology and Criminal Justice 211, 212.

14 Rule 4.1.

15 Maher (n 1) 493. 
define the age of criminal responsibility in the latter sense. The UNCRC does not specify a minimum crime age.

The UN Committee on the Rights of the Children (UN Committee) - the executive body that administers the UNCRC - sets 12 as the 'absolute minimum age' of criminal responsibility. For children below age 12, 'the irrefutable assumption is that they cannot be formally charged and held responsible in the penal law procedure'. The UN Committee clarifies that: 'States Parties are encouraged to continue to increase their minimum age of criminal responsibility to a higher age level' - but not to lower it, if it is currently above $12 .{ }^{16}$

In parallel, international law stipulates a minimum age below which it should not be permitted to deprive children of their liberty ${ }^{17}$ - perhaps termed the 'minimum age of freedom penalty' - and, accordingly, the 'absolute minimum age' may be termed as the 'minimum age of entry' (to the penal system). This combination provides a narrow definition of the age of criminal responsibility in international law.

The 17th Congress of the International Association of Penal Law (International Congress of Penal Law) ${ }^{18}$ specifies that, to a child below age 14, only educational measures may be applied. This means that, whilst for children at or above 12 (the minimum age of entry) at the time of offending, but younger than age 14 (the minimum age of freedom penalty), penal law procedures can be applicable, ${ }^{19}$ but only educational measures may be applied as a means of disposal for their wrong-doing.

The international law appears to allow a gap between the two age limits to recognise the variations of juvenile justice practices: in some jurisdictions, such as Scotland, the age of entry is very low, but only educational and welfare-based measures, as opposed to penal penalties and freedom penalties in particular, are permitted for offending juveniles below a higher age. ${ }^{20}$ This illustrates that international law is primarily concerned with the best interests of children in conflict with the law ${ }^{21}$ and prevents them being incarcerated at young ages.

In addition to the age rules, international law also provides the general principles and specific requirements which govern the way in which offending juveniles should be dealt with in state systems.

\section{INTERNATIONAL LAW: THE TREATMENT OF JUVENILES IN CONFLICT WITH THE LAW}

The Beijing Rules suggest that conventional, punitive measures are not appropriate and their use should be minimised; alternatives should be developed, focused upon the wellbeing of the juvenile. ${ }^{22}$ This recommendation is incorporated into the UNCRC. Article 40.3(b) specifies 'whenever appropriate and desirable, measures for dealing with such children without resorting to judicial proceedings, providing that human rights and legal safeguards are fully respected'. This provision essentially imposes an obligation on

16 Comments 31-33.

17 Rule 11(a), JDLs.

18 It resolved the 'Justification of the Principle of Criminal Liability and the Different Categories of Age' in José Luis De La Cuesta (ed), Resolutions of the Congress of the International Association of Penal Law (1926-2004) $<$ www.penal.org/sites/default/files/files/RICPL.pdf > 156-58.

19 Comments 31-33, CRC 2007.

20 Howard League for Penal Reform, 'Punishing Children: A Survey of Criminal Responsibility and Approaches across Europe' (Howard League for Penal Reform 2008) 7; Maher (n 1).

21 UNCRC, Article 3.

22 Rule 17. 
contracting states to minimise the use of penal law measures so as to reduce the harm that may be caused to juveniles by criminalisation and punitive disposals, such as custody. ${ }^{23}$ International law is clearly informed by research findings and is evidence-based. ${ }^{24}$

In addition to justifying a separate juvenile justice system from that of adult offenders which requires different treatment for children, the CRC 2007 stresses:

The protection of the best interests of the child means, for instance, that the traditional objectives of criminal justice, such as repression/retribution, must give way to rehabilitation and restorative justice objectives in dealing with child offenders. ${ }^{25}$

Alternatives, such as educational measures, that focus on the rehabilitation of the individual child offender are specifically promoted under the International Congress of Penal Law. 26

These international instruments require national governments to adopt welfare-based approaches that are 'rooted in inquisitorial, adaptable, informal, needs-oriented and childspecial processes 27 and, wherever possible, to avoid conventional justice measures.

It appears that the broad definition of the age of criminal responsibility in the context of international law is presented in two sets of rules: the first safeguards offending juveniles by ensuring they are not brought into the penal system; the second prevents juveniles from being dealt with by punitive measures that are proven as harmful to them. It is worth noting that, in practice, the international law often serves only as 'useful campaign tools for those with an interest in juvenile justice'. ${ }^{28}$ Ultimately, it is the responsibility of nation states to determine whether or not, and if so, how to translate those instruments into national policy and practice. Apart from the willingness of national governments, there are also technical difficulties in identifying a global understanding of international law: there are 'substantial translational disjunctures between international standards and national policies' and this has rendered 'multitudinous and widely varying forms' of juvenile justice policies in the world. ${ }^{29}$ Consequently, the CRC 2007 concludes that 'many States Parties still have a long way to go in achieving full compliance with the UNCRC',30 although this might not be the result of intentional failure to comply with international norms and standards, which may be interpreted differently across diverse national perspectives.

Breach of the minimum age rules is easy to identify, highlight and criticise, ${ }^{31}$ whereas violation of the second set of requirements is not so obvious and is often overlooked, especially in the areas of 'procedural rights, the development and implementation of

23 UNCRC, Article 1.

24 For example, Uberto Gatti, Richard E Tremblay and Frank Vitaro, 'Tatrogenic Effect of Juvenile Justice' (2009) 50(8) Journal of Child Psychology and Psychiatry 991; Lesley McAra and Susan McVie, 'Youth Justice? The Impact of System Contact on Patterns of Desistance from Offending' (2007) 4(3) European Journal of Criminology 315.

25 Comment 10.

26 Recommendation 3, see De La Cuesta (n 18).

27 Goldson and Hughes (n 13) 212.

28 Howard League for Penal Reform (n 20) 5.

29 Goldson and Hughes (n 13) 213.

30 Comment 1, CRC 2007.

31 See, for example, Muncie (n 8) 6; Barry Goldson, "Unsafe, Unjust and Harmful to Wider Society": Grounds for Raising the Minimum Age of Criminal Responsibility in England and Wales’ (2013) 13(2) Youth Justice 111; Howard League for Penal Reform (n 20). 
measures for dealing with children in conflict with the law without resorting to judicial proceedings, and the use of deprivation of liberty only as a measure of last resort'. ${ }^{32}$

Admittedly, other factors also need to be considered while determining national rules on age and crime for juveniles. The Beijing Rules, for example, bring the notion of responsibility for criminal behaviour of children along with 'other social rights and responsibility' and 'civil majority'.33 Likewise, the CRC 2007 suggests that, while responding to children who offend, states parties should serve 'not only the best interests of these children but also the short- and long-term interest of the society at large'. ${ }^{34}$ The interests of society, specifically in the context of public protection, need to be considered along with the interests of children who offend.

For policymakers in China, public opinion is an additional matter of concern. China adopts 'authoritarian populist justice', 35 where radical shifts in public policy, such as incorporating the international norm of juvenile justice into the national system, usually require a high level of public support before the policy can be made and then implemented.

Undoubtedly, international law has had an impact on law, policy and practice in juvenile justice in many jurisdictions, including China. Whilst the international requirements are still violated by states parties, ${ }^{36}$ so far no evidence suggests that China has been singled out for poor compliance. This is perhaps owing to the fact that Chinese law is largely in line with international norms and standards in terms of the age of criminal responsibility and it continues to make efforts, slowly, to improve its system and practice to afford further protection for juvenile offenders. For example, since 2011 the eighth revised criminal law prohibits classifying juveniles below the age of 18 who have been convicted previously as 'repeat offenders' so that aggravated sentences cannot be imposed on them. However, so far much attention has been paid to compliance with the first set of requirements, whilst implementation of the second set of rules, which embodies the principles of diversion, minimum necessary intervention, proportionality and decarceration, is not strongly demonstrated in juvenile justice policies and practices in China.

\section{Law, policy and practice in juvenile justice in China}

While the adult criminal justice system in China remains largely punitive, juvenile justice is an exception. ${ }^{37} \mathrm{With}$ the influence of international law and practices in other regulatory domains, the Chinese system increasingly operates on core principles of the international agreements on the protection of children and young people.

As noted above, apart from recognising the minimum age of criminal responsibility, the PRC has long had special rules to differentiate juveniles from adult offenders in terms of their treatment in criminal justice processes. Since the 1990s, the idea of child protection has been strengthened in China and the starting point is the two child-specific enactments - the Law on the Protection of Minors 1991 (LPM 1991) and the Law on Prevention of Juvenile Offending 1999 (LPJO 1999) - both are applicable to children

\footnotetext{
Comment 1, CRC 2007.

3 Commentary to rule 41.

34 Comments 3 and 10.

35 Benjamin L Liebman, 'A Populist Threat to China's Courts?' in Margaret Y K Woo and Mary E Gallagher (eds), Chinese Justice: Civil Dispute Resolution in Contemporary China (CUP 2011) 269, 270.

36 Muncie (n 8).

37 Anqi Shen and Steve Hall, 'The Same the Whole World Over? A Review Essay on Youth Offending and Youth Justice in China' (2014) 43 International Journal of Law, Crime and Justice 273.
} 
Ages 14 and 15: relative criminal responsibility
Formal measures - court orders (CCL)

- Parents exercising supervision

- Shelter for rehabilitation by state

\section{Informal measures}

- Specialised schools for school age juveniles, i.e. the study-work school (LPM; LPJO)

- Bangjiao
Ages 14 and 15: responsible for 8 offences

Age 16 and above: full criminal responsibility

Ages 14-18: lesser or mitigated punishment

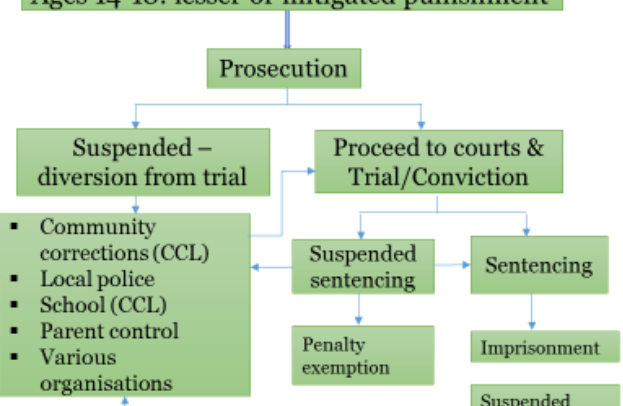

imprisonment

Figure 1: The rules on age and crime: procredures and measures for juvenile offenders in China

below the age of 18. International law, the Beijing Rules in particular, appears to underpin this positive move.

Both statutes address the underlying principles in response to juvenile delinquency and crime in China. One positions education as the primary measure of intervention over punishment, which should only be used as a supplementary means; the other provides that 'measures dealing with offending juveniles shall combine education, ganhua and rescue'. ${ }^{38}$ The term ganhua is hard to define in solid terms but can be thought of as a concept or a method in the context of early intervention and offender rehabilitation. The notion of ganhua is based on the Mencian belief which broadly means using informal measures to persuade and influence behaviour change of a (young) person. ${ }^{39}$ These principles were inserted into the Criminal Procedural Law when it was revised in $2012 .{ }^{40}$

It is well acknowledged that there is a strong emphasis in the Chinese system on rehabilitation through education, the use of informal mechanisms and the crucial role of the society as the initial means to reintegrate children and young people who offend. This national practice is supported by traditional Chinese beliefs and is also consistent with core principles expressed in the international legal framework that seeks to unify global policymaking in juvenile justice. Figure 1 illustrates current juvenile justice policy and practice in China and, in addition, shows where informal measures are positioned in the system.

As Figure 1 shows, both formal and informal measures are available for children who have reached the age of relative criminal responsibility, committed offences outside the eight grave crimes and are therefore immune from penal law. These children may be subject to two formal measures - the parental supervision order and the order of shelter for rehabilitation by the state - both are intended to be educational, as distinct from justice, disposals. Although the law offers no implementation details for these measures, it recognises a need for special treatment for these children. There are also informal measures which I will return to below. 
Formal disposals in Chinese law for juveniles who have reached the age of full criminal responsibility are essentially the same as those for adult offenders, with the exception of the death penalty. The principal punishments available for juvenile offenders include public surveillance, criminal detention, fixed-term imprisonment and the life sentence, among which public surveillance is the only non-custodial sentence. Given its specified legal requirements, this form of criminal penalty is not commonly used for juveniles.

Currently, community sentences are unavailable in China. Juvenile law-breakers may have their custodial sentences suspended, but all of the criteria must be met. ${ }^{41}$ Since the rules governing suspension of prison sentences are strict, in reality, incarceration may be inevitable for a significant number of juvenile offenders, once they are brought into criminal justice processes. ${ }^{42}$

Along with formal procedures, there are informal measures for juvenile offenders in China. In fact, informal crime control has been a key feature of the Chinese criminal justice system, especially in response to juvenile offending 43 and bangizao and the studywork schools are the most renowned informal mechanisms for juveniles. ${ }^{44}$

Bangizao is a broad term covering varied forms of community crime control programmes which are educational and run on a voluntary basis by communities and social institutions in partnership with state agencies, for example, designated local police officers. It aims at monitoring, assisting and rehabilitating offenders. Bangjiao started from the early days of the PRC as an informal crime prevention mechanism for those involved in minor offending. The Comprehensive Treatment Strategy, which started in 1990, requires the cooperative participation of all agencies and the use of coordinated multiple educational measures in response to crime. ${ }^{45}$ For years, community care through bangizao was recognised as successful in crime control for juveniles. ${ }^{46}$ However, with the change of socio-economic circumstances and a more mobile population, the measure came to be regarded as a helpful embellishment rather than an effective measure in itself. ${ }^{47}$ Today, bangïao is often used as a supplementary corrective facility to provide community support for juveniles serving prison sentences and even after their release, in addition to those subjected to community corrections. 48

There are two principal problems with bangizao. First, as an informal measure, it is not clearly defined. It relies largely on voluntary work from various agencies, with no

41 See CCL 1997, s 72.

42 Shun'an Wang and Bin Han, 'Achievement, Problems and Solutions of Juvenile Justice in China' (2014) 6 Juvenile Justice 50, 54.

43 Dennis S W Wong, 'Changes in Juvenile Justice in China' (2001) 32 Youth and Society 492.

44 Bong-ho Mok, 'Community Care for Delinquent Youth: The Chinese Approaches of Rehabilitating Young Offenders' (1990) 15(2) Journal of Offender Community Service Rehabilitation 5; Jianhong Liu and George B Palemo, 'Restorative Justice and Chinese Traditional Culture in the Context of Contemporary Chinese Criminal Justice System’ (2009) 7(1) Asian Pacific Journal of Police and Criminal Justice 49; Shen (n 9); Anqi Shen and Georgios A Antonopoulos, 'Restorative Justice or What? Restorative Justice in the Chinese Youth Justice System’ (2013) 21 European Journal of Law and Criminal Justice 291.

45 Dawei Wang, 'The Study of Juvenile Delinquency and Juvenile Protection in the People's Republic of China' (2006) 22(94) Crime and Justice International 4.

46 Lening Zhang, Dengke Zhou, Steven F Messner, Allen E Liska, Marvin D Krohn, Jianhong Liu and Zhou $\mathrm{Lu}$, 'Crime Prevention in a Communitarian Society: Bangjiao and Tiaojie in the People's Republic of China' (1996) 13 Justice Quarterly 199.

47 Chang Liu, 'The Theoretical Reconstruction of China's Juvenile Justice System and Future Directions: With Particular Reference to the British Youth Justice System’ (2011) 15(293) Forward Position 94.

48 Lirong Wang, 'An Important Attempt for Crime Prevention: The First Community Services Order in China' (2003) 3(29) People's Procuratorate 12. See detailed discussion in Shen and Hall (n 37). 
identifiable procedure and resources to guarantee consistency, availability and achievement of the intended outcomes; and, second, there is no clear evidence to show its effectiveness. Therefore, it may be said that the use of bangjiao is institutionally promoted, rather than evidence-supported.

The study-work school is an informal early intervention measure exclusively available for school-age juveniles who are considered 'at risk' of law-breaking and who have already come to be in contact with the law for minor offences. The study-work school was designed with clear reformative and educative goals and was previously recognised as a successful welfare-based intervention for juveniles. However, its use has declined in recent decades due to a combination of factors, including, inter alia, the shortage of evidence to indicate the impact of the operation of early intervention in this context. Thus, like bangizao, the studywork school has not been used in a systematic manner across the country and currently does not appear to be a frequently used disposal for juvenile law-breakers. ${ }^{49}$

Restorative justice was introduced to China in the early 2000s, offering an innovative alternative mechanism to conventional punitive justice for juveniles. A number of programmes have been attempted under the name of restorative justice which aim at diversion and minimum intervention by seeking to deal with juvenile wrong-doers outside legal institutions, thereby diverting them from criminalisation and punishment. ${ }^{50}$ Among these newly developed programmes, 'suspended prosecution' and 'suspended sentencing' are pioneering. These align with restorative justice principles and exemplify China's effort to embrace the ideas of integration, restoration and protection in its juvenile justice practices.

Suspended prosecution, also known as 'delay in prosecution', has been adopted as a pilot scheme in several regions in China. It enables prosecutors to temporarily have their cases involving juvenile suspects who admit wrong-doing to be placed on hold. Rather than being prosecuted, the juveniles are placed within the community and subject to educational programmes through bangjiao. It is hoped that during the probationary periods various agencies will work together to achieve the best results for the juveniles concerned and ultimately enable them to be diverted from the judicial process.

Similarly, suspended sentencing started as a pilot scheme at the Changning District Court in Shanghai. Under the scheme, judges are allowed to exercise discretion and have the sentencing stage suspended in cases involving juvenile offenders who admit guilt of the offences that are charged against them. During the pre-sentencing periods, juveniles are subject to the bangijao programmes and some are expected to attend school. If they perform well and refrain from further criminal engagement during the probationary periods, sentencing is deemed no longer necessary. ${ }^{51}$ The purpose is to divert these juveniles from criminal punishment and represents an ostensible attempt by the Chinese judiciary to depart from conventional justice practices.

Both pilot schemes are intended to encourage behaviour change, integration and confidence-building of juvenile law-breakers outside formal procedures and work towards the direction of lifting juveniles out of the criminal justice system - an approach to child-centred juvenile justice promoted by international law. However, they share several problems. Firstly, both schemes primarily involve personnel from legal institutions - prosecutors and members of the judiciary - and therefore are part of formal criminal justice processes. Juvenile offenders are not, therefore, entirely immune from the penal

49 See detailed discussion in Shen (n 9).

50 Shen and Antonopoulos (n 44).

51 Xiaorong Gu and Xiang Guo, 'China Criminal Responsibility of Minors in National and International Legal Order’ (2004) 1(75) International Review of Penal Law 660, 670. 
system, thus rendering harmful consequences - labelling, criminalisation, negative social reaction and stigma ${ }^{52}$ - inevitable. Secondly, a lack of solid legal basis for these innovative measures has raised the issue of legality and prevented them being widely applied. Currently, suspended prosecution is mainly operated locally often on a small scale, under the internal regulations of the procuratorate. ${ }^{53}$ The use of suspended sentencing is also restrained. Thirdly, the effectiveness of these newly developed measures has not been evaluated in a robust manner perhaps due to methodological difficulties and other factors. According to Changning District Court, its pilot scheme was successful as none of the 29 juvenile delinquents who were part of it re-offended during the pre-sentencing probationary periods. ${ }^{54}$ Other than that, no further evidence appears to be available.

Similar attempts have been made in juvenile justice practices in China to improve the system. However, as Figure 1 illustrates, informal and welfare-based measures, although available, are limited and, as previously pointed out, there are fundamental problems that hinder the development of innovative, divergent and non-punitive measures for juveniles in need.

China does have institutional arrangements and operational practices that, if running as they are designed, are capable of achieving the goal of the international law as regards juvenile justice. However, China's problem is arguably the slow development of welfarebased, non-criminal measures for juvenile offenders. In addition, some practices, such as the range of sentences available, are at odds with the core principles underpinning international law that aim to divert the majority of offending juveniles from legal institutions, formal processes and criminal sanctions. Admittedly, as many jurisdictions in the world, China faces tension between the international norm of child protection and public and government's long-standing concerns over security and social order. ${ }^{55}$ With the seemingly worsened reality of juvenile delinquency and crime, there are calls for reforms to toughen policy and practice as a public reaction - a sign of a worrying turn towards punitiveness in juvenile justice.

\section{The reality of juvenile offending and calls for reform}

It is observed that rapid economic growth over the past four decades has brought with it an increase in crime; statistically there seems to be an upsurge in juvenile offending in China. ${ }^{56}$ Chinese writers have intensively expressed their concerns over these upswinging trends, new patterns and alarmingly sophisticated characteristics of juvenile criminality. ${ }^{57}$ Children are found to offend at very young ages, ${ }^{58}$ they use the same methods as those typically employed by adult offenders, and their criminal actions often result in very

52 Howard S Becker, Outsiders: Studies in the Sociology of Deviance (Macmillan 1963); Edwin M Lemert, Human Deviance, Social Problems and Social Control (Englewood Cliffs 1967); Franklin E Zimring, American Juvenile Justice (OUP 2005); Barry Goldson (ed), Youth in Crisis? 'Gangs', Territoriality and Violence (Routledge 2011).

53 Shen and Antonopoulos (n 44).

54 Gu and Guo (n 51) 670.

55 Guoling Zhao, 'Juvenile Criminal Justice System in China' in Liqun Cao, Ivan Y Sun and Bill Hebenton (eds), Routledge Handbook of Chinese Criminology (Routledge 2014) 103.

56 Shen and Hall (n 37).

57 Jianlong Yao, 'Juvenile Delinquency Control in Transitional Societies: A Study on the National Pilot Scheme on the Juvenile Risk Groups and the Prevention of Crime' (2012) 4 Social Sciences 63.

58 Qing Ju, 'A Quantitative Analysis on the Trend of Chinese Youth Offending' (2007) 5 Issues of Youth Offending 15; Yi Han, 'Rethinking to Legislate on Juvenile Offending: With a Particular reference to the Age of Quasi-Criminal Liability' (2006) 1 Legal Studies 65, 67. 
serious consequences. ${ }^{59}$ The public reaction is typically a general call for tougher policies on crime control against offending children and young people.

Public debate became heated in 2013 after an atypical tragedy involving the torture of an 18-month-old baby boy in a lift by a 10-year old girl, who later took him home and threw him out of a building from her balcony on the 25 th floor. ${ }^{60}$ In reaction to this serious incident involving the child 'offender' and to juvenile crime in general, a widespread belief arose that children mentally and socially mature earlier today than their counterparts in the past when the law was created. Therefore, the argument goes, it is reasonable now to hold younger children accountable for serious wrong-doing. It is thought that reducing the age of criminal responsibility, thereby placing offending children in the criminal justice system, might deter potential child law-breakers ${ }^{61}$ although claiming children develop quicker in contemporary China is not supported by any solid evidence.

Some commentators ${ }^{62}$ have observed a lack of effective measures in dealing with 'offending' children below the age of criminal responsibility. They claim that shelter for rehabilitation is not frequently ordered due to a shortage of facilities; the parental supervision order is also hardly used as it is thought that juvenile law-breaking is often a result of poor parenting and those parents lack capacity to supervise their children effectively and to help them with behaviour change. Moreover, it is argued that detailed procedural law is not available to guide the use of existing mechanisms. Rather than calling for creating new, effective mechanisms, they propose lowering the minimum crime age so as to place younger age children in the formal criminal justice system. ${ }^{63}$ It is true that doing nothing cannot be accepted as a responsive state reaction that 'primarily takes into account the best interests of these juveniles', according to international standards. ${ }^{64}$ However, lowering the minimum crime age is certainly unhelpful as it serves to remove these juveniles "from the category of "child" altogether' 65 and exposes them to the substantive criminal law as adults. ${ }^{66}$

There are academic writers in China who seek support from international law for lowering the age of criminal responsibility. For example, Zhong and Lin turn to rule 4.1 of the Beijing Rules and interpret it as follows:

The Rule says that the facts of emotional, mental and intellectual maturity of children should be considered. This is to say that it is children's actual capacity to understand the wrongfulness of their actions and actual capacity to control their actions that matters. Given the current social circumstances in China, lowering

59 Han (n 58) 67.

60 Xinhua News, 5 December 2013 <http://news.xinhuanet.com/politics/2013-12/05/c_125808871.htm>.

61 See Rongrong Zheng and Yuchi Liu, 'An Analysis of the Feasibility of Lowering the Age of Criminal Responsibility in China' (2015) 3 (Zhong) Law and Society 246, 246; Xiaoying Li, 'Considering the Issue of Lowering the Age of Criminal Responsibility' (2006) 6 Academic Journal of Henan Institute of Cadres for Legal and Political Administration 137, 138; Liuying Ma, Research on the Criminal Justice Treatment for Juveniles (Intellectual Property Press 2009) 111-12; Xun Zhang, 'New Ideas on Fixing the Age of Criminal Responsibility' (2010) 22(4) Journal of Sichuan Police College 17; Jun Zhong and Xiaomei Lin, 'Crime Increasingly Involving Juveniles of Very Young Ages and the Reform of the Age of Criminal Responsibility' (2009) 22(2) Journal of Shanxi College for Youth Administrators 73, 73, 75.

62 For example, Gu and Guo (n 51) 666; Zhong and Lin (n 61).

63 Zhong and Lin (n 61) 75.

64 UNCRC, Article 3.

65 Chris Jenks, Childhood 2nd edn (Routledge 2005) 128.

66 Goldson (n 52). 
the minimum crime age should be acceptable and would be supported by the general public. ${ }^{67}$

This interpretation is problematic for two reasons. First, no evidence is available to affirm the social circumstances in China that justify lowering the age of criminal responsibility; second, rule 4.1 is taken out of the international legal framework as a whole and misinterpreted, irrespective of the core principles embodied in international law that promote the best interests of children in conflict with the law. ${ }^{68}$

Some Chinese scholars ${ }^{69}$ search for evidence through comparative law. Typically, the laws of foreign jurisdictions which adopt low ages of criminal responsibility are cited in support of the lowering of the minimum crime age in China. However, often the 'intrinsic intricacies and overarching complexities' of comparative law are overlooked. ${ }^{70}$ More seriously, factual errors are found in comparative articles 'citing' foreign law, policy and practices. One scholar, ${ }^{71}$ for example, called for urgently lowering the age of criminal responsibility in China as was the case - it is claimed with no referencing details - in the UK where the Home Office was working on a proposal to lower the age of 'problem children' from 13 to 8 . The claim ignores the fact that, in response to the UN Committee's criticisms, raising the minimum crime age has been strongly advocated across jurisdictions in Britain. ${ }^{72}$ This exemplifies the 'methodological hazards' 73 of comparative law: one is the possibility of misreading or simplifying local context and reading foreign law, policy and practice uncritically. ${ }^{74}$ Linguistic incompetence may be another problem, ${ }^{75}$ as anything less than complete fluency may leave one vulnerable to misinterpretation. ${ }^{76}$ The Chinese case illustrates problems in comparative academic research and, in this instance, the authors have rendered the reading of foreign laws unhelpful.

There are also Chinese scholars who support the existing rules on age and crime but argue that the law should be refined. ${ }^{77}$ Yao, for example, contends that setting 14 as the minimum age of criminal responsibility is appropriate because it not only reflects the

67 Zhong and Lin (n 61) 76.

68 UNCRC, Article 3; Comments 31-33, CRC 2007.

69 For example, Jibao Zhang, 'Discuss Necessity of Lowering the Age of Full Criminal Responsibility' (2012) 8 (Zhong) Law and Society 247; Yao Yao, 'Preliminary Discussion on Lowering the Minimum Age of Criminal Responsibility in China' (2012) 7 Products and Quality 213; Zhong and Lin (n 61).

70 Goldson and Hughes (n 13) 214.

$71 \mathrm{Li}(\mathrm{n}$ 61) 138.

72 For England and Wales, see, for example, Rob Allen, From Punishment to Problem Solving: A new Approach to Children in Trouble (Centre for Crime and Justice Studies 2006); Muncie (n 8). For Scotland, see, for example, Maher (n 1). For Northern Ireland, see Northern Ireland Department of Justice, A Review of the Youth Justice System in Northern Ireland (Northern Ireland Department of Justice 2011).

73 Francis Pakes, Comparative Criminal Justice 2nd edn (Willan 2010) 22.

74 Lucia Zedner, 'Comparative Research in Criminal Justice' in Lesley Noaks, Michael Levi and Mike Maguire (eds), Contemporary Issues in Criminology (University of Wales Press 1995) 8.

75 Frank Leishman, 'Policing in Japan: East Asian Archetype?' in Rob I Mawby (ed), Policing across the World: Issue for the Twenty-first Century (Routledge 1999) 109.

76 Zedner (n 74).

77 For example, Xingwang Chen and Juanjuan Chen, 'Problems of the Minimum Age of Criminal Responsibility in Chinese law and Restructure' (2006) 15(2) Journal of Beijing Youth Politics College 43; Jianlong Yao, 'Theoretical Examination of Criminal Responsibility in Relation to Juveniles in China' (2006) 3 Journal of Northwest China College of Law and Political Science 147; Mingxuan Gao, Specialised Discussions on the Criminal Law, 1st Section (Higher Education Press 2002). 
circumstances in China but is consistent with international law, in addition to the policy and practice of many other countries. ${ }^{78}$ However, the scope of grave offences relevant to the age of relative criminal responsibility needs to be reconsidered to include only very serious crimes that are commonly identified across cultures. ${ }^{79} \mathrm{Han}$, in contrast, argues that the current scope of grave offences is too narrow, considering the aims of penal policy and the policy concerning juveniles' well-being and their protection in China. 80 Echoing Han, Gao suggests that, for the purpose of crime prevention and public protection, juveniles who have reached 14 years of age should be held criminally liable for offences that may not be very serious but are clearly harmful and prevalent among juveniles, such as theft, snatching, fraud and sexual assault. ${ }^{81}$ Apparently, the latter views represent an effective lowering of the age of full criminal responsibility from 16 to 14 and therefore represent a departure from the international standards.

China, like other state parties, continues to face a balancing exercise between 'care' and 'control' in juvenile justice and the tension between the protection of children who offend and the safety of the public at large. Often, when juvenile crime becomes an issue of great public concern, criminalisation tends to be favoured over diversions. Concerns over crime control and community safety trigger calls for lowering the age of criminal responsibility, ${ }^{82}$ meaning that the further development of needs-based measures to tackle the structural problems of juvenile offending are put on hold.

\section{Conclusion}

Although international law, the CRC in particular, has not been incorporated into domestic legislation in China, its age of criminal responsibility is not too low, as far as international benchmarks are concerned. China accepts that children and young people deserve particular protection and offending juveniles are treated differently from adult criminals in the Chinese system. Following the global trend, child-centred juvenile justice strategies continue to be developed in China where criminal justice processes are typically perceived to have a punitive tradition. Despite various difficulties and challenges, a series of developments have been made in recent years, as this article illustrates. However, like many other systems, much needs to be done in China to fully accord with the core principles of international law as regards juvenile justice: securing immunity from prosecution, developing welfare-based measures, and minimising the use of incarceration for juvenile offenders.

Clearly, China's problem is not so much about settling the age of criminal responsibility, nor is about its resistance to international law, but more to do with a lack of 'sympathetic understanding' necessary for compliance with it - a problem shared with other states parties. ${ }^{83}$ For China, there is an urgent need to develop a comprehensive and accurate knowledge of international law in order to address issues, such as: what should a welfare-based system for juveniles look like? What can be done to develop diversional

\footnotetext{
78 Yao (n 77) 152.

79 Ibid 156.

80 Han (n 58) 69, 70.

81 Gao (n 77) 212.

82 David Smith and Kiyoko Sueda, 'The Killing of Children by Children as a Symptom of National Crisis: Reactions in Britain and Japan' (2008) 8(1) Criminology and Criminal Justice 5.

83 Bruce Abramson, Juvenile Justice: The 'Unwanted Child' of State Responsibilities - An Analysis of the Concluding Observations of the UN Committee on the Rights of the Child, in Regard to Juvenile Justice from 1993 to 2000 (International Network on Juvenile Justice/Defence for Children International 2000).
} 
disposals and other alternatives to incarceration? What are disproportionate sentences? And what amounts to excessive use of custody?

The second area of development for China is the implementation of law and policy. The first step should be to provide detailed procedural laws and designated resources to better develop the aforementioned welfare-based system. It is also essential that new and existing strategies are supported by 'research-based knowledge and practice-based evidence'. ${ }^{84}$ This type of evidence-based approach must be adopted when utilising existing non-punitive mechanisms and creating new measures to remove juveniles from the reach of the penal system. The law must be updated to afford legislative support for new and innovative, welfare-based measures.

International law as regards juvenile justice is primarily concerned with how children who offend should be dealt with by states. It provides a framework for the development of global child-friendly juvenile justice ${ }^{85}$ that pays attention to the special needs of those juveniles and promotes their rehabilitation. It is important that nation states do not simply determine the age at which it is necessary to hold juveniles criminally responsible for their serious wrong-doing, but to assess 'the age at which it is appropriate to draw children into the penal system at all'. ${ }^{86}$

This article, which details law, policy and practice in juvenile justice in China, serves as a case study in the context of comparative law. It shows that comparative research is useful in exploring the widely varied approaches towards juvenile justice in different countries, helping to identify developing trends that appear to reflect the global approach to juvenile offending and punishment. ${ }^{87}$ Comparative juvenile justice offers a unique opportunity to 'examine critically and theorise the contradictions and inconsistencies that underpin both the global trends and the manifest counter movement' that characterise contemporary international juvenile justice. ${ }^{88} \mathrm{It}$ is useful, for China, to learn and possibly transfer policy and practices from other jurisdictions, ${ }^{89}$ whilst continuing with existing and developing new innovative juvenile justice measures of its own.

84 Goldson and Hughes (n 13) 213.

85 Barry Goldson and John Muncie, 'Towards A Global “Child Friendly” Juvenile Justice' (2011) 40 International Journal of Law, Crime and Justice 47.

86 Thomas Crofts, 'Catching up with Europe: Taking the Age of Criminal Responsibility Seriously in England' (2009) 17(4) European Journal of Crime, Criminal Law and Criminal Justice 267; 269.

87 Howard League for Penal Reform (n 20).

88 Goldson and Hughes (n 13) 214.

89 Neal Hazel, Cross-National Comparison of Youth Justice (Youth Justice Board 2008). 
